\title{
FAKTOR-FAKTOR YANG MEMPENGARUHI PENANAMAN MODAL DALAM NEGERI (PMDN) DI SUMATERA BARAT
}

\section{FACTORS AFFECTING DOMESTIC INVESTMENT (PMDN) IN WEST SUMATERA}

\author{
Engla Desnim Silvia \\ Universitas Putra Indonesia "YPTK" Padang \\ Jl. Raya Lubuk Begalung Padang. Telp. (0751) 776666, 73000 Fax. (0751) 71913 \\ engladesnim1986@ymail.com
}

Naskah diterima 02 Juli 2018, di-review 23 Oktober 2018, disetujui 12 Nopember 2018

\begin{abstract}
This paper aims to analyze the factors that influence domestic investment in West Sumatera. The type of research is descriptive and associative ones. The data were secondary and time series with a certain time period. Data were collected through literature studies, and analyzed descriptively and inductively by using multicollinearity test, heterokedasitas test, autokorelasi test, normality test, coefficient of determination $\left(R^{2}\right)$, multiple linear analysis, $t$ test, and f test. The findings of the research shows there is a significant influence between gross domestic regional products, security, and credit interest rates towards domestic investment in West Sumatera. It was obtained $F_{\text {hitung }}=15,174>F_{\text {table }}=3,49$ and level sig $=0,000<\alpha=0,05$. This show that gross domestic regional products, , security, and credit interest rates significantly effect the domestic investment in West Sumatera. It is recommended the government need to improve the security by ensuring the safety of the investors' efforts from all crimes that have a direct or indirect impact on investors.
\end{abstract}

Keywords: gross domestic regional product, security, and credit interest rate

\begin{abstract}
Abstrak: Tulisan ini bertujuan untuk menganalisis faktor-faktor yang mempengaruhi investasi dalam negeri di Sumatera Barat. Jenis penelitiannya adalah deskriptif dan asosiatif. Data merupakan data sekunder dan time series dengan periode waktu tertentu. Data dikumpulkan melalui studi pustaka, dan dianalisis secara deskriptif dan induktif dengan menggunakan uji multikolinieritas, uji heterokedasitas, uji autokorelasi, uji normalitas, koefisien determinasi (R2), analisis linier berganda, uji T, dan uji F. Temuan penelitian menunjukkan ada pengaruh yang signifikan antara produk domestik bruto daerah, keamanan, dan suku bunga kredit terhadap investasi domestik di Sumatera Barat. Diperoleh F hitung $=15,174>\mathrm{F}$ tabel $=3,49$ dan tingkat sig $=0,000<\alpha=0,05$. Hal ini menunjukkan bahwa produk domestik bruto, keamanan, dan suku bunga kredit berpengaruh signifikan terhadap investasi dalam negeri di Sumatera Barat. Disarankan pemerintah perlu meningkatkan keamanan dengan memastikan keamanan upaya para investor dari semua kejahatan yang memiliki dampak langsung atau tidak langsung pada investor.
\end{abstract}

Kata kunci: produk domestik regional bruto, keamanan, dan suku bunga kredit

\section{PENDAHULUAN}

$S^{3}$ alah satu tantangan dalam menggerakkan pertumbuhan ekonomi ke depan adalah meningkatkan investasi, karena peranan investasi dalam pembangunan ekonomi mutlak diperlukan untuk meningkatkan modal sebagai sumber pembiayaan pembangunan yang akan dilaksanakan. Jika modal yang tersedia cukup besar, maka pembangunan akan lebih lancar karena dapat dilakukan investasi kepada sektorsektor ekonomi. Peningkatan investasi tidaklah mudah, dalam mendorong peningkatannya perlu dilakukan upaya-upaya yang maksimal terutama 
dalam menggerakkan investasi swasta dalam negeri, diantaranya adalah dengan menciptakan stabilitas keamanan bagi para investor. Untuk itu perlu upaya-upaya serius dari para pihak, khususnya di daerah-daerah yang dirasakan kurang kondusif dari situasi keamanan, konflik sosial, politik dan sebagainya, untuk segera memperbaiki kondisi sosial politiknya. Dalam hal ini harus ada upaya dari pihak-pihak yang berwenang untuk mensosialisasikan bahwa secara umum kondisi sosial politik di Indonesia terutama tingkat keamanan, cukup kondusif untuk melakukan investasi. Perlu adanya pemetaan daerah-daerah berdasarkan tingkat keamanannya agar tidak terjadi generalisasi terhadap kondisi keamanan Indonesia yang akan merugikan bagi upaya peningkatan investasi apalagi untuk meningkatkan penanaman modal di Sumatera Barat.

Upaya pemerintah daerah dalam penghimpunan dana pembangunan terutama di Sumatera Barat adalah dengan berusaha menggalakkan investasi swasta yang dilakukan oleh dunia usaha terutama Penanaman Modal Dalam Negeri (PMDN) dan Penanaman Modal Asing (PMA), dimana nilai investasi diharapkan dapat mendorong dan mengangkat pertumbuhan ekonomi. Untuk itu harus diperhatikan faktorfaktor yang mempengaruhinya seperti yang dijelaskan di atas. Bila diperhatikan investasi di Sumatera Barat dalam beberapa tahun terakhir memperlihatkan peningkatan yang cukup tinggi. Hal ini dapat dilihat dari tabel berikut:

Tabel 1

Realisasi Investasi PMDN dan PMA

di Sumatera Barat

\begin{tabular}{|r|r|r|}
\hline \multicolumn{3}{|c|}{ Realisasi Investasi } \\
\hline 2003 & PMDN (juta rupiah) & \multicolumn{1}{|c|}{ PMA (ribu us\$) } \\
2004 & 204.465 & 42.286 \\
2005 & 81.154 \\
2006 & 631.733 & 61.326 \\
2007 & 607.061 & 107.591 \\
2008 & 621.170 & 118.552 \\
2009 & 685.383 & 129.340 \\
2010 & 718.031 & 129.533 \\
2011 & 767.773 & 185.569 \\
2012 & 783.978 & 181.154 \\
2013 & 813.234 & 161.326 \\
2014 & 804.465 & 177.591 \\
& & 931.733 \\
\hline
\end{tabular}

Sumber : Badan Pusat Statistik (BPS) Sumatera Barat

Menurut Hamid (2006: 56) banyak studi menemukan bahwa pelaksanaan Otonomi Daerah (Otoda) telah memperburuk iklim investasi. Masih rendahnya pelayanan publik, kurangnya kepastian hukum, dan berbagai Perda yang tidak pro bisnis, pelayanan publik yang dikeluhkan terutama terkait dengan ketidakpastian biaya dan lamanya waktu berurusan dengan perizinan dan birokrasi.

Investasi yang lazim juga disebut dengan istilah penanaman modal atau pembentukan modal. Dengan demikian menurut (Sukirno, 2002: 107) investasi diartikan sebagai pengeluaran atau perbelanjaan penanaman modal perusahaan untuk 
membeli barang-barang modal dan perlengkapanperlengkapan produksi untuk menambah kemampuan memproduksi barang-barang dan jasa-jasa yang tersedia dalam perekonomian.

Jadi investasi merupakan suatu pengeluaran yang dilakukan untuk meningkatkan atau mempertahankan persedian barang modal. Investasi merupakan salah satu komponen utama dalam mencapai pertumbuhan ekonomi. Dengan arti kata besarnya laju pertumbuhan ekonomi yang dicapai ditentukan juga oleh besarnya investasi yang dilakukan.

Investasi dalam praktiknya, meliputi tiga komponen dalam usaha untuk mencatat nilai penanaman modal yang dilakukan dalam satu tahun tertentu, meliputi pengeluaran/ perbelanjaan sebagai berikut (Sukirno, 2000: 122):

1. Pembelian berbagai jenis barang modal, yaitu mesin-mesin dan peralatan produksi lainnya untuk mendirikan berbagai jenis industri dan perusahaan.

2. Perbelanjaan untuk perumahan, bangunan kantor, pabrik dan lainnya

3. Pertambahan nilai stok barang-barang yang belum terjual.

Kegiatan investasi memungkinkan suatu masyarakat terus menerus meningkatkan kegiatan ekonomi dan kesempatan kerja, meningkatkan pendapatan nasional dan meningkatkan taraf kemakmuran masyarakat, peranan ini bersumber dari tiga fungsi penting dari kegiatan investasi (Sukirno, 2000: 367), pertama investasi merupakan salah satu komponen dari pengeluaran agregat. Maka kenaikan investasi akan meningkatkan permintaan aggregat dan pendapatan nasional.
Peningkatan seperti ini akan selalu diikuti oleh pertambahan dalam kesempatan kerja. Kedua, pertambahan barang modal sebagai akibat investasi akan menambahkan kapasitas memproduksi di masa depan dan perkembangan ini akan menstimulir pertambahan produksi nasional dan kesempatan kerja. Ketiga, investasi selalu diikuti oleh perkembangan teknologi. Perkembangan ini memberi sumbangan penting ke atas kenaikan produktifitas dan pendapatan per kapita masyarakat.

Menurut ekonomi klasik, adanya tabungan masyarakat tidak berarti dana tersebut hilang dari peredaran, tetapi dipinjamkan atau dipakai oleh pengusaha untuk membiayai investasi. Di mana pengusaha bersedia membayar bunga selama keuntungan yang diperoleh dari investasi lebih besar dari bunga tersebut.

Sedangkan menurut Keynes sifat antara hubungan suku bunga dan investasi mempunyai hubungan yang berkebalikan atau berlawanan arah. Pada saat tingkat suku bunga tinggi, maka tingkat investasi adalah rendah, sebaliknya apabila terjadi pengurangan dalam tingkat suku bunga maka akan meningkatkan investasi. Jadi dapat disimpulkan bahwa semakin tinggi tingkat suku bunga, maka investasi akan turun, sedangkan penurunan tingkat suku bunga akan meningkatkan investasi.

Menurut Keynes penambahan uang akan menurunkan tingkat bunga, sebagai akibat kelebihan likuiditas tingkat bunga turun sehingga permintaan uang sama dengan jumlah uang. Turunnya tingkat bunga menyebabkan kenaikan investasi sehingga pendapatan naik. 
Menurut Tandelilin (2001: 4) investasi juga merupakan fungsi dari tingkat suku bunga, di mana makin tinggi tingkat bunga, maka keinginan untuk melakukan investasi juga akan kecil. Alasannya seorang pengusaha akan menambah pengeluaran investasinya apabila keuntungan yang diharapkan dari investasi tersebut yang merupakan ongkos untuk penggunaan dana. Makin rendah tingkat suku bunga, maka pengusaha akan lebih terdorong melakukan investasi, sebab biaya penggunaan dana tersebut makin kecil. Dengan demikian agar terjadi peningkatan investasi atau penanaman modal, maka tingkat bunga diharapkan dapat diturunkan atau dalam kondisi yang stabil.

Teori tingkat bunga menurut klasik adalah bagian dari penggunaan dana yang tersedia untuk dipinjamkan (loanable fund). Harga ini terjadi di pasar dana investasi, istilah pasar dana investasi dapat dijelaskan bahwa dalam periode ada anggota masyarakat yang menerima pendapatan yang melebihi kebutuhan konsumsi masyarakat tersebut, kemudian menabungkan kelebihan pendapatannya, jumlah seluruh tabungan mereka membentuk penawaran akan loanable funds.

Di pihak lain, dalam periode yang sama ada masyarakat atau pengusaha yang memerlukan dana untuk investasi. Keseluruhan dari investasi atau dana mereka akan membentuk permintaan akan loanable funds, selanjutnya para penabung dan para investor ini akan bertemu dipasar loanable funds. Dari proses tawar menawar antara mereka akhirnya akan dihasilkan tingkat bunga keseimbangan sebagai harga dari loanable funds yang digunakan oleh para investor.
Apabila terjadi kenaikan tingkat bunga, hal ini akan mendorong kenaikan jumlah dana yang akan ditabung oleh masyarakat dan apabila tingkat bunga mengalami penurunan maka akan terjadi sebaliknya. Akan tetapi untuk para investor, apabila terjadi kenaikan tingkat bunga, maka hal ini tentunya menurunkan permintaan akan loanable funds dan jika terjadi penurunan tingkat bunga maka akan mendorong terjadinya kenaikan permintaan loanable funds oleh investor.

Penawaran akan dana investasi (S) dalam kondisi penggunaan tenaga kerja penuh (full employment) yang bertemu dengan permintaan akan dana investasi (I) di pasar dana investasi (loanable funds) akan menimbulkan suatu tingkat bunga keseimbangan dimana $\mathrm{S}=\mathrm{I}$ pada saat kondisi full employment.

Menurut Sukirno (2002: 18) pendapatan nasional adalah istilah yang menerangkan barang-barang dan jasa-jasa yang diproduksikan suatu negara dalam suatu tahun tertentu. Dalam kebanyakan analisis mengenai penentuan pendapatan nasional pada umumnya investasi yang dilakukan para pengusaha adalah berbentuk investasi otonomi. Walau bagaimanapun, pengaruh pendapatan nasional terhadap investasi tidak boleh diabaikan. Di mana tingkat pendapatan nasional yang tinggi akan memperbesar pendapatan masyarakat, yang selanjutnya pendapatan masyarakat yang tinggi tersebut akan memperbesar permintaan terhadap barang-barang dan jasa, maka keuntungan perusahaan akan bertambah tinggi dan ini akan mendorong dilakukannya lebih banyak investasi. Dengan kata lain, apabila pendapatan bertambah tinggi maka investasi akan bertambah tinggi pula (Sukirno, 2002: 115). 
Jadi dapat disimpulkan bahwa pendapatan nasional juga mempengaruhi investasi yang ada. Di mana semakin tinggi pendapatan nasional maka akan meningkatkan investasi, keadaan ini juga berlaku sebaliknya. Investasi yang demikian dinamakan dengan investasi terpengaruh atau investasi yang jumlahnya ditentukan/ dipengaruhi oleh tinggi rendahnya pendapatan nasional.

Menurut Badan Pusat Statistik (2005: 3) pendapatan regional atau Produk Domestic Regional Bruto (PDRB) didefinisikan sebagai jumlah nilai tambah yang dihasilkan oleh seluruh unit usaha dalam suatu wilayah tertentu, atau merupakan jumlah nilai barang dan jasa akhir yang dihasilkan oleh seluruh unit ekonomi, baik PDRB atas harga konstan maupun atas harga berlaku. PDRB atas harga konstan menunjukkan nilai tambah barang dan jasa yang dihitung menggunakan harga pada satu tahun tertentu sebagai dasar, di mana dalam penghitungan ini digunakan tahun dasar 2000. Sedangkan PDRB atas harga berlaku menggambarkan nilai tambah barang dan jasa yang dihitung menggunakan harga pada setiap tahun.

Dari uraian di atas disimpulkan bahwa untuk mengetahui besarnya Product Domestic Regional Bruto (PDRB) dapat dilihat dari harga konstan dan harga berlaku, di mana harga berlaku dihitung berdasarkan pada harga-harga yang berlaku pada tahun tersebut dan harga konstan dihitung berdasarkan harga pada satu tahun tertentu yang dijadikan dasar untuk menghitung PDRB pada tahun berikutnya. Di mana unit-unit produksi tersebut disajikan menurut lapangan usaha yaitu:
1. Pertanian, Peternakan, Kehutanan dan Perikanan.

2. Pertambangan dan Penggalian

3. Industri Pengolahan

4. Listrik, Gas dan Air Bersih

5. Bangunan

6. Perdagangan, Hotel dan Restoran

7. Pengangkutan dan Komunikasi

8. Keuangan, Persewaan dan Jasa Perusahaan

9. Jasa-jasa termasuk jasa pelayanan pemerintah

Menurut pendekatan Pengeluaran, PDRB adalah semua komponen permintaan akhir seperti: 1. Pengeluaran konsumsi rumah tangga dan lembaga swasta

2. Konsumsi pemerintah

3. Pembentukan modal tetap domestic bruto

4. Perubahan stok

5. Ekspor neto dalam jangka waktu tertentu (biasanya satu tahun). Ekspor neto merupakan ekspor dikurangi impor.

Secara konsep ketiga pendekatan tersebut memberikan jumlah yang sama antara jumlah pengeluaran dengan jumlah barang dan jasa akhir yang dihasilkan dan harus sama pula dengan jumlah pendapatan untuk faktor-faktor produksinya.

Namun otonomi daerah ini dan pembiayaannya mempunyai tujuan untuk mempercepat pertumbuhan ekonomi daerah dan sekaligus mewujudkan keadilan ekonomi dan sosial di daerah. Hal ini mengakibatkan terjadinya perubahan dalam susunan pengambilan kebijakan dalam hal persetujuan penanaman modal, penerapan peraturan masing-masing daerah, keterbatasan potensi dan pembiayaan pembangunan, sehingga akan mempengaruhi jumlah investasi untuk tahun berikutnya. 
Peningkatan penanaman modal dalam negeri (PMDN) ini, tentunya akan menunjang pembangunan ekonomi dalam suatu daerah termasuk di Sumatera Barat. Berdasarkan uraian di atas, penulis tertarik untuk melihat bagaimana perkembangan PMDN (investasi dalam negeri) dan faktor-faktor yang mempengaruhinya di Sumatera barat yang dilihat secara makro ekonomi yang berjudul "Faktor-faktor yang mempengaruhi Penanaman Modal Dalam Negeri (PMDN) di Sumatera Barat"

\section{METODE PENELITIAN}

Jenis penelitian ini adalah deskriptif dan asosiatif. Penelitian deskriptif bertujuan menggambarkan peristiwa atau kejadian, variabel penelitian dan juga untuk menemukan ada atau tidaknya pengaruh antara variabel bebas dengan variabel terikat, di mana data yang digunakan berupa data yang berbentuk angka. Asosiatif bertujuan untuk melihat adanya hubungan antara variabel-variabel bebas yaitu PDRB, keamanan dan suku bunga kredit terhadap penanaman modal dalam negeri (PMDN).

Sesuai dengan tujuan penelitian yaitu untuk mengetahui pengaruh variabel bebas yaitu PDRB (X1), keamanan (X2), dan suku bunga kredit (X3) terhadap variabel terikat (Y) PMDN, maka dapat diturunkan persamaan fungsi sebagai berikut:

$$
\mathrm{Y}=\alpha \mathrm{X} 1 \beta 1 \mathrm{X} 2 \beta 2 \mathrm{X} 3 \beta 3 \ldots \mathrm{Xi} \beta \mathrm{i} . . . . \mathrm{Xn} \beta \mathrm{n} \text { e u }
$$

Kemudian untuk menganalisis data, maka persamaan 2 diubah dalam bentuk logaritma yang dikenal dengan istilah double log transformation, maka persamaannya menjadi:

132 | Engla Desnim Silvia $\log Y=\log \alpha+\beta 1 \log X 1+\beta 2 \log X 2+\beta 3 \log X 3+u$

Uji-t adalah untuk mengetahui apakah variabel yang ditaksir mempunyai hubungan yang berarti, maka pengujian t-test dilakukan untuk variabel tersebut. Uji F pengujian ini dilakukan untuk melihat hubungan antara variabel bebas dengan variabel tak bebas secara keseluruhan. Hasil pengujian ini juga akan dibandingkan dengan nilai yang ada pada Tabel $\mathrm{F}$.

Uji Multikolinearitas merupakan salah satu syarat untuk memakai analisis dengan menggunakan Regresi Linear Berganda terlebih dahulu dilakukan Uji Multikolinearitas yaitu uji hubungan sesama variabel bebas. Uji Normalitas Sebaran Data adalah uji berguna untuk mengetahui apakah data yang dianalisis berdistribusi secara normal maka sebelum pemakaian statistik dilakukan Uji Normalitas. Uji Auto Korelasi berarti terdapatnya korelasi antara data pengamatan yang diukur berdasarkan waktu, sehingga satu data yang satu dipengaruhi oleh data yang lainnya. Sedangkan Uji Homogenitas digunakan untuk melihat apakah varians homogen atau tidak.

\section{PEMBAHASAN DAN HASIL}

Berdasarkan pengolahan data dengan bantuan program SPSS, diperoleh hasil olahan data untuk berbagai uji dan model analisis sebagai berikut:

Multikolinearitas yaitu adanya hubungan yang kuat antara variabel bebas dalam persamaan regresi. Adanya multikolinearitas menyebabkan adanya ketidakpastian estimasi, sehingga mengarahkan kesimpulan yang menerima hipotesis 0 (nol). Hal ini menyebabkan 
koefisien elastisitas menjadi tidak signifikan. Untuk mengetahui terdapat atau tidaknya multikolinearitas dapat dilakukan dengan cara membandingkan koefisien korelasi product moment dengan nilai kritisnya yaitu $\alpha=0,05$. Dengan bantuan SPSS, maka didapat hasil korelasi antara variabel bebas sebagaimana dapat dilihat dari tabel di bawah ini:

Tabel 2

Hasil Uji Multikolinearitas

\begin{tabular}{|c|c|c|c|}
\hline & LOG X1 & LOG X2 & LOG X3 \\
\hline $\begin{array}{l}\text { LOG X1 Pearson Correlation } \\
\text { Sig. (2-tailed) } \\
\mathrm{N}\end{array}$ & $\begin{array}{r}1 \\
16\end{array}$ & $\begin{array}{r}.021 \\
.938 \\
16\end{array}$ & $\begin{array}{r}-.365 \\
.164 \\
16\end{array}$ \\
\hline $\begin{array}{l}\text { LOG X2 Pearson Correlation } \\
\text { Sig. (2-tailed) } \\
\mathrm{N}\end{array}$ & $\begin{array}{r}.021 \\
.938 \\
16 \\
\end{array}$ & 16 & $\begin{array}{r}-.323 \\
.222 \\
16\end{array}$ \\
\hline $\begin{array}{l}\text { LOG X3 Pearson Correlation } \\
\text { Sig. (2-tailed) } \\
\mathrm{N}\end{array}$ & $\begin{array}{r}-.365 \\
.164 \\
16 \\
\end{array}$ & $\begin{array}{r}-.323 \\
.222 \\
16 \\
\end{array}$ & 16 \\
\hline
\end{tabular}

Sumber: Diolah dengan SPSS

Dari hasil di atas dapat dilihat bahwa tidak ada pengaruh yang signifikan antara sesama variabel bebas. Dengan demikian ketiga variabel bebas dalam penelitian ini dapat dianalisis sekaligus dengan menggunakan model regresi berganda atau asumsi klasik penggunaan model ini dapat terpenuhi. Uji Normalitas adalah data yang mempunyai pola seperti distribusi normal (data tersebar secara normal). Distribusi data dikatakan tidak tersebar secara normal apabila nilai sig $<\alpha$ dan data dikatakan tersebar secara normal apabila sig $>\alpha$. Hasil pengujian data dengan one-sample kolmogorov-smirnov dapat dilihat pada Tabel di bawah ini:

Tabel 3

Hasil Uji Normalitas Dengan One-Sample Kormogorov- Smirnov

\begin{tabular}{|l|l|l|}
\hline \multicolumn{1}{|c|}{ Variabel } & \multicolumn{1}{c|}{ Signifikansi } & \multicolumn{1}{c|}{ Keterangan } \\
\hline PDRB (X1) & 0,692 & Normal \\
Keamanan $(X 2)$ & 0,972 & Normal \\
Suku bunga kredit (X3) & 0,223 & Normal \\
PMDN (Y) & 0,844 & Normal \\
\hline
\end{tabular}

Sumber: Data diolah

Auto korelasi yaitu adanya hubungan yang 1990-2005, dari analisis data penelitian uji signifikan yang muncul pada data deret waktu. autokorelasi dilakukan dengan rumus DurbinPenelitian ini menggunakan data kurun waktu Watson yang dapat dilihat pada tabel di bawah ini:

Tabel 4

Hasil Uji Durbin-Watson

\begin{tabular}{|l|l|l|l|l|}
\hline Model & \multicolumn{1}{|c|}{$\mathbf{R}$} & \multicolumn{1}{c|}{ R Square } & Adjusted R Square & \multicolumn{1}{c|}{ Durbin-Watson } \\
\hline 1. & 0,890 & 0,791 & 0,739 & 1,759 \\
\hline
\end{tabular}

Sumber: Data diolah

Dari hasil perhitungan yang diperoleh dengan penelitian ini yaitu 1,759, maka dapat disimpulkan bantuan SPSS, didapat nilai Durbin-Watson pada bahwa tidak terdapat auto korelasi, karena jika 
dibandingkan dengan tabel Durbin-Watson, nilai data pengamatan terletak pada 1,55-2,46, jadi tidak terdapat autokorelasi.Untuk menentukan apakah data yang berasal dari keempat variabel homogen atau tidak, maka dilakukan uji homogenitas variabel, baik variabel X1, X2, X3, dan X4, maupun Y. Hasil uji homogenitas keempat variabel dapat dilihat pada tabel beikut ini:

Tabel 5

Hasil Uji Homogenitas

One-Sample Kormogorov-Smirnov

\begin{tabular}{|l|r|l|}
\hline \multicolumn{1}{|c|}{ Variabel } & Sig & \multicolumn{1}{|c|}{ Keterangan } \\
\hline LOG X1 & 0,213 & Homogen \\
LOG X2 & 0,922 & Homogen Homogen Homogen \\
LOG X3 & 0,066 & \\
LOG Y & 0,298 & \\
\hline
\end{tabular}

Sumber : Data diolah

Berdasarkan tabel 4.9 di atas dapat dilihat bebas terhadap variabel terikat. Dari hasil bahwa variabel X1, X2, dan X3 serta variabel Y adalah homogen karena sig $>\alpha(0,05)$. Estimasi Model Regresi, analisis ini digunakan untuk mengetahui kontribusi masing-masing variabel penelitian ini dapat ditentukan besarnya pengaruh PDRB, keamanan, dan suku bunga kredit terhadap PMDN di Sumatera Barat yang diperlihatkan oleh persamaan regresi berikut:

Tabel 6

Nilai Penduga Koefisien Regresi

\begin{tabular}{|l|l|r|r|r|r|l|}
\hline No. & Variabel & Koefisien & Nilai $t_{\text {hitung }}$ & Parsial $r^{2}$ & Sig & Ket \\
\hline 1. & (constant) & $-2,172$ &,- 936 & & 0,368 & - \\
2. & Log X1 & 0,961 & 3,286 & 0.4733 & 0,007 & Ha diterima \\
3. & Log X2 & 0,257 & 2,564 & 0.3540 & 0,025 & Ha diterima \\
4. & Log X3 & $-0,439$ & $-2,874$ & -0.4083 & 0,014 & Ha diterima \\
\hline
\end{tabular}

Sumber: Data diolah

Berdasarkan Tabel di atas dapat dibuat persamaan regresi berganda sebagai berikut: $\log Y=\log a+b_{1} \log X_{1}+b_{2} \log X_{2}+b_{3} \log X_{3}+u$ $\log Y=\log -2,172+0,961 \log X_{1}+0,257 \log$ $X_{2}-0,439 \log X_{3}$

Menurut persamaan regresi berganda di atas maka koefisien $r^{2}=0,791 \%$ artinya sumbangan yang diberikan oleh variabel bebas terhadap variabel terikat adalah sebesar 79,1\%. Hal ini menunjukkan 79,1\% variabel PDRB, Keamanan dan suku bunga kredit mempengaruhi PMDN di Sumatera Barat dan 20,9 \% dipengaruhi oleh faktor -faktor lain.
Uji t dilakukan dengan menggunakan $t_{\text {hitung }}$ dan menggambarkan probabilitas yang dihitung dengan tingkat kepercayaan 95\% ( $\alpha=0,05$ $\mathrm{df}=12$ ) maka nilai $\mathrm{t}_{\text {tabel }}$ dalam penelitian ini adalah 2,179. Pengkajian hipotesis bersamasama atau secara keseluruhan dilakukan dengan menggunakan uji F. Jika $F_{\text {hitung }}$ lebih besar dari $F$ tabel maka hipotesis nol harus ditolak dan hipotesis Ha harus diterima, yang artinya bahwa secara bersama-sama variabel bebas berpengaruh signifikan terhadap variabel terikat. Di bawah ini akan disajikan tabel Analisis Varians (ANOVA). 
Tabel 7

Hasil Uji ANOVA

\begin{tabular}{|l|r|r|r|r|r|r|}
\hline \multicolumn{1}{|c|}{ Model } & Sum of Square & \multicolumn{1}{c|}{ Df } & Mean square & F & Sig & Ket. \\
\hline Regresion & 0,616 & 3 & 0,205 & 15,174 & 0,000 & Ho ditolak \\
Residual & 0,162 & 12 & 0,014 & & & \\
Total & 0,779 & 15 & & & & \\
\hline
\end{tabular}

Sumber : Data diolah

Dari Tabel dapat dilihat bahwa sig yang diperoleh adalah $0,000<\alpha=0,05$ atau dalam pengujian ini diperoleh nilai $\mathrm{F}_{\text {hitung }} 15,174>\mathrm{F}_{\text {tabel }}$ 3,49. Nilai F ini memperlihatkan bahwa secara bersama-sama PDRB, keamanan, dan suku bunga kredit mempunyai pengaruh yang signifikan terhadap PMDN di Sumatera Barat

\section{Hasil}

Pengaruh PDRB (X1), Keamanan (X2), dan suku bunga kredit (X3), secara bersama-sama terhadap PMDN (Y) Sumatera Barat.

Berdasarkan olahan data dapat diketahui bahwa hipotesis yang menyatakan bahwa terdapat pengaruh yang signifikan antara PDRB, keamanan dan suku bunga kredit secara bersama-sama terhadap PMDN Sumatera Barat terbukti diterima. Dimana diperoleh $\mathrm{F}_{\text {hitung }=} 15,174>\mathrm{F}_{\text {table }}=3,49$ dan taraf sig $=0,000<\alpha=0,05$. Hal ini menunjukkan bahwa PDRB, keamanan dan suku bunga kredit secara bersama-sama berpengaruh siginifikan terhadap PMDN Sumatera Barat.

Hal ini sesuai dengan pembahasan sebelumnya bahwa kenaikan dalam PDRB akan menaikkan jumlah PMDN Sumatera Barat, dimana tingkat pendapatan yang tinggi akan memperbesar pendapatan masyarakat dan selanjutnya pendapatan masyarakat yang tinggi tersebut akan memperbesar permintaan terhadap barang-barang dan jasa sehingga akan mendorong dilakukannya lebih banyak investasi. Dan terciptanya tingkat keamanan bagi para investor akan meningkatkan gairahnya untuk menanamkan investasi karena adanya rasa aman dalam suatu daerah. Dengan demikian kondisi yang kondusif merupakan modal bagi suatu daerah untuk meningkatkan penanaman modalnya.

Sedangkan kenaikan dalam suku bunga kredit akan menurunkan jumlah PMDN di Sumatera Barat dan juga akan terjadi sebaliknya, dimana penurunan dalam suku bunga kredit akan meningkatkan PMDN Sumatera Barat. Pada saat suku bunga kredit tinggi kondisi ini akan menyulitkan dunia usaha/ investor karena keuntungan yang mereka harapkan akan berkurang.

Dengan demikian dari hasil pengujian didapat bahwa pengaruh antara suku bunga kredit terhadap PMDN di Sumatera Barat adalah signifikan. Hal ini sesuai dengan pendapat Klasik bahwa investor bersedia membayar bunga selama keuntungan yang diperoleh dari investasi lebih besar dari bunga tersebut. Demikian juga menurut Jhingan (2004 : 133) yang menyatakan bahwa investasi tergantung dari efisiensi marginal dari modal dan suku bunga. Efisiensi marginal dari modal merupakan tingkat hasil yang diharapkan. Bila tingkat laba tinggi perusahaan akan melakukan investasi lebih banyak.

Secara bersama-sama sumbangan dari PDRB, keamanan dan tingkat suku bunga kredit terhadap PMDN Sumatera Barat adalah 79,1 
persen. Ini berarti bahwa 20,9 persen PMDN di Sumatera Barat dipengaruhi oleh faktor faktor lain yang tidak diteliti dalam penelitian ini, diantaranya adalah teknologi, daya beli masyarakat, kebijakan pemerintah serta faktorfaktor lain yang mempengaruhinya

\section{PENUTUP}

\section{Kesimpulan}

Berdasarkan olahan data dapat diketahui bahwa hipotesis yang menyatakan bahwa terdapat pengaruh yang signifikan antara PDRB, keamanan dan suku bunga kredit secara bersamasama terhadap PMDN Sumatera Barat terbukti diterima. Dimana diperoleh $\mathrm{F}_{\text {hitung }} 15,174>\mathrm{F}$ table $=3,49$ dan taraf sig $=0,000<\alpha=0,05$. Hal ini menunjukkan bahwa PDRB, keamanan dan suku bunga kredit secara bersama-sama berpengaruh siginifikan terhadap PMDN Sumatera Barat.

\section{Saran}

Disarankan kepada pemerintah agar selalu berusaha meningkatkan keamanan dengan menjamin keselamatan berusaha para investor dari segala tindak kejahatan baik yang berdampak langsung maupun tidak langsung terhadap investor. Dalam penelitian ini suku bunga kredit berpengaruh secara signifikan terhadap PMDN, untuk itu diperlukan peran pemerintah dalam mengendalikan kenaikan suku bunga dengan kebijakan moneter serta dengan memperhatikan situasi ekonomi makro Negara kita. Di samping itu disarankan kepada peneliti selanjutnya untuk meneliti hubungan instrumen bagi hasil dalam ekonomi Islam dengan kebijakan moneter.

\section{DAFTAR KEPUSTAKAAN}

Bank Indonesia. 2010 Laporan Perekonomian Indonesia (LPI) dan Statistik Ekonomi dan Keuangan Indonesia (SEKI). BI: Jakarta 2004. Survei Iklim Investasi. BI: Jakarta

Badan Pusat Statistik. Statistik Indonesia. Berbagai Edisi. Padang. (Statistik Indonesia). bps.go.id. Diakses 25 Mei 2011.

Basri, Faisal. 2002. Perekonomian Indonesia: Tantangan dan harapan bagi Kebangkitan ekonomi Indonesia. Jakarta:Erlangga.

Dornbusch, Rudiger, Stanley Fischer, dan Richard Startz (2008). Makroekonomi. Edisi kesepuluh. Alih bahasa Roy Indra Mirazudin. Jakarta: PT. Media Global Edukasi

Case, Karl E dan Fair Ray C. 2003. Prinsip-prinsip Ekonomi Mikro. Edisi ketujuh. Alih Bahasa Barlian Muhamad. Jakarta: Gramedia .2007. Prinsip-Prinsip Ekonomi. Edisi Kedelapan. Alih Bahasa Wibi Hardani dan Devri Barnadi. Jakarta: Erlangga

Chardiman, 2006. Pengaruh Investasi Swasta terhadap pertumbuhan ekonomi di Kabupaten Agam, Tesis (S2), Universitas Negeri Padang. Edy Suanti, Hamid 2004. Memperkokoh Otonomi Daerah, Yogyakarta:UII Press

Jhingan, M. L. 2004. Ekonomi Pembangunan dan Perencanaan. Jakarta:Rajawali Persada Lipsey, Richard G, Paul N. Courant, Douglas D. Purvis, dan Peter O. Steiner. 1997. Pengantar Makroekonomi, Jilid 2. Alih bahasa Agus Maulana. Binarupa Aksara. Jakarta. 
VOLUME 2, NOMOR 2, DESEMBER 2018

Sukirno, Sadono. 2001. Pengantar Makro ekonomi. Tandelilin, Eduardus, 2001. Analisis Investasi dan Jakerta:PT Raja Grafindo Persada Manajemen Portfolio, Yogyakarta:BPFE 2004. Pengantar Teori Makro.

Jakarta:PT Raja Grafindo Persada

Faktor-Faktor yang Mempengaruhi Penanaman Modal dalam Negeri (PMDN) di Sumatera Barat || 137 